\title{
Shell Growth Pattern and Percentage Flesh Yield of the West African Clam, Galatea paradoxa (Born, 1778) from Itu Creek, Niger Delta Nigeria
}

\author{
*V.F. Akinjogunla and R.O. Moruf \\ Department of Fisheries and Aquaculture, Bayero University, Kano, Kano State Nigeria \\ [*Corresponding Author: E-mail: vicakin@yahoo.com; $\mathbf{E}:+2348092643007]$
}

ABSTRACT: Shell Morphometry is a fundamental tool for the evaluation of phenotypic stocks. The shell growth pattern and percentage flesh yield of Galatea paradoxa from Itu Creek in Niger Delta were investigated using standard morphometric methods. The mean in centimeter $(\mathrm{cm})$ of $9.71 \pm 0.09$, $35.02 \pm 0.22,23.21 \pm 0.12,37.11 \pm 0.25,29.31 \pm 0.16$ and $7.32 \pm 0.04$ were recorded for shell length, maximum width, maximum height, nacre length, nacre width and hinge length respectively. Mean live weight of $115.70 \pm 1.09 \mathrm{~g}$, mean flesh weight of $37.91 \pm 0.23 \mathrm{~g}$ and mean shell weight of $66.82 \pm 0.97 \mathrm{~g}$ were recorded for this species. Galatea paradoxa showed negative allometric growth $(b<3)$ while the correlation coefficients ( $r$ ) in all the shell variables were far below '1', indicating a week correlation between the parameters. About $19 \%$ of the live weight of the clam is made up of flesh by weight.

Keywords: Bivalve, Clam, Shell dimension, Niger Delta.

\section{INTRODUCTION}

The Phylum, Mollusc is known to radiate successfully into a variety of habitats; the great majority of which are aquatic while some are found mostly in shallow waters and sometimes in intertidal zones where they burrow into the mud in the beds of the river which serves as their habitat. Clams, oysters and mussels are bivalve molluscs which are highly popular, nutritious and commercially available in southern parts of Nigeria. They are relatively cheap source of animal protein and the shells have been affirmed as good feedstuff in animal feed formulation (Moruf and Akinjogunla, 2018). World production of bivalve has been gradually increased over the last two decades due to reflection of strong demand (Gallardi et al., 2014). The availability of commercially important bivalve resource will probably reach the over exploitation level in future, if the harvesting of shellfish is still carried out continuously from natural habitats in coastal zone without implementing sustainable fishery management practices (Kumar et al., 2018). The knowledge of growth pattern which can be useful for the population assessment of the species will be needed in planning sustainable aquaculture and fishery management practices.
The West African Clam, Galatea paradoxa (Donacidae), is a bivalve mollusc that is largely abundant in a few large rivers in West Africa countries like Cross and Nun (Nigeria), Sanaga (Cameroon) and the Volta (Ghana) (AdjeiBoateng et al., 2009). The species is a very common bivalve species found almost throughout the coastal regions of Nigeria (Adeyemo et al., 2013); it spawns and develops mostly in freshwater environment. However, if transferred into the stagnant water like dams, it will still grow but may not reproduce, and the meat would be less palatable (Ikpeme and Johnny, 2018). In Itu Local Government Area of Akwalbom State, it is heavily harvested by artisanal fishermen except during the wet season when the water level is high. This act puts pressure on the very young members of the species; hence the need for conservation measures to be applied (Ikpeme and Johnny, 2018). A number of environmental factors which influence shell properties of bivalve species include water quality, depth, turbulence and current, quality of phytoplankton, type of sediment, amongst others (Obirikokang et al., 2013).

Growth morphometric studies can be used to evaluate fishery stocks, population dynamics and 


\section{Akinjogunla and Moruf: Shell Growth Pattern and Percentage Flesh Yield of the West African Clam...}

to describe "phenotypic stocks" (Guimaraes-Silva et al., 2015). Shellfish length and weight relationship (LWR) is a fundamental indicator for stock assessment and the growth parameter contributes to the knowledge of its growth pattern estimation. The increasing strong demand of mollusc as food in southern Nigeria, together with the dearth of information on growth dimensions of clam assemblages in Nigeria has prompted this study. Therefore, the study aimed at investigating the shell growth pattern and soft tissue weight of the clam species, Galatea paradoxa in Itu Creek of Niger Delta.

\section{MATERIALS AND METHODS \\ Sample collection}

Samples of the G. paradoxa were obtained between April and September 2018 from artisanal fishers operating around the Itu creek in Akwa Ibom State. The sampling site is geographically located at $5^{\circ} 39^{\prime} 0{ }^{\prime \prime}$ North, $8^{\circ} 1$ ' 0" East. Random sampling was carried out between 17.00 and 19.00 hours on monthly bases. A total of eight hundred and sixteen (816) specimens were used in the study. The samples were ice-packed in coolers and transported to Department of Marine Sciences of the University of Lagos, Nigeria for analysis.

\section{Morphometric Measurement}

Shell dimensions were measured (to the nearest $0.01 \mathrm{~cm}$ ) using a Grip Vernier Caliper of $0.5 \mathrm{~cm}$ precision, while the weights were measured in gram using Electronic Compact Scale (atoma110C). The morphometrics include maximum dimension of the anterior-posterior axis (shell length), anterior-posterior length (maximum width), maximum distance between the external surfaces of the two valves when they are closed (maximum height), distance from the hinge to the end of the nacre layer inside the shell (nacre length), maximum distance between the anterior and posterior margin of the nacre layer (nacre width), maximum distance between the tips of the anterior and posterior ears along the hinge line of the clam (hinge length). These morphometric characters were measured and recorded in proformas for each clam before dissection. The statistical width/length - weight relationships were established using the parabolic equation below.

$W=a L^{b} \ldots \ldots \ldots \ldots . . I$ (Pauly 1983)

$\mathrm{W}=$ Total weight of clam's shell in gram $(\mathrm{g})$ $\mathrm{L}=$ Length of clam's shell in centimetre $(\mathrm{cm})$ $a=$ Regression constant (intercept) $b=$ Regression coefficient (slope)

Relationship was transformed into a straight line logarithm:

$\log W=\log a+b \log L \quad \|$

(Parsons, 1988)

\section{Statistical Analysis}

Data generated were presented as mean \pm standard error (descriptive statistics) using Microsoft Excel 2010 while co - efficient of determination $\left(r^{2}\right)$ was used to determine quality of linear regression.

\section{RESULTS}

The values of tissue weight and shell morphometric of Galatea paradoxaare are presented in Table 1. The ranges in $\mathrm{cm}$ from 3.41 to $16.02(9.71 \pm 0.09), \quad 11.02$ to 64.00 (35.02 \pm 0.22$), 9.11$ to 40.21 (23.21 \pm 0.12$), 8.04$ to $73.32(37.11 \pm 0.25), 7.03$ to $45.13(29.31 \pm 0.16)$ and 3.03 to $12.04(7.32 \pm 0.04)$ were recorded for shell length, maximum width, maximum height, nacre length, nacre width and hinge length respectively. Mean live weight of $115.70 \pm 1.09 \mathrm{~g}$, mean flesh weight of $37.91 \pm 0.23 \mathrm{~g}$ and mean shell weight of $66.82 \pm 0.97 \mathrm{~g}$ were recorded for this species. About $19 \%$ of the live weight of clam is made up of flesh by weight. 
Nigerian Journal of Basic and Applied Science (December, 2019), 27(2): 119-126

Table 1: Growth dimensions of the West African Clam, Galatea paradoxa from Itu Creek

\begin{tabular}{lccl}
\hline \multicolumn{1}{c}{ Dimensions } & Minimum & Maximum & Mean \pm StandardError \\
\hline Shell Length (SL) cm & 3.41 & 16.02 & $9.71 \pm 0.09$ \\
Maximum Width (MW) cm & 11.02 & 64.00 & $35.02 \pm 0.22$ \\
Maximum Height (MH) cm & 9.11 & 40.21 & $23.21 \pm 0.12$ \\
Nacre Length (NL) cm & 8.04 & 73.32 & $37.11 \pm 0.25$ \\
Nacre width (NW) cm & 7.03 & 45.13 & $29.31 \pm 0.16$ \\
Shell volume (SV) ml & 110 & 230 & $133 \pm 1.01$ \\
Hinge Length (HL) cm & 3.03 & 12.04 & $7.32 \pm 0.04$ \\
Live weight (LW)g & 98.21 & 219.28 & $115.70 \pm 1.09$ \\
Flesh weight (FW)g & 18.38 & 51.89 & $37.91 \pm 0.23$ \\
Shell weight (SW) g & 25.44 & 158.39 & $66.82 \pm 0.97$ \\
Percent flesh yield (\%) & 9.90 & 63.83 & $18.72 \pm 0.02$ \\
\hline
\end{tabular}

The shell dimension - weight relationships are illustrated in Figures 2 - 9. The exponent ' $b$ ', varied from 0.5792 (maximum height - shell length) to 2.4733 (shell weight - shell length). The value of "b", 2.261 in Figure 1 showed that the West African Clam exhibited a negative allometric growth pattern while the correlation coefficient (r), 0.7763 indicates a strong correlation (close to ' 1 ') between its shell length and live weight.

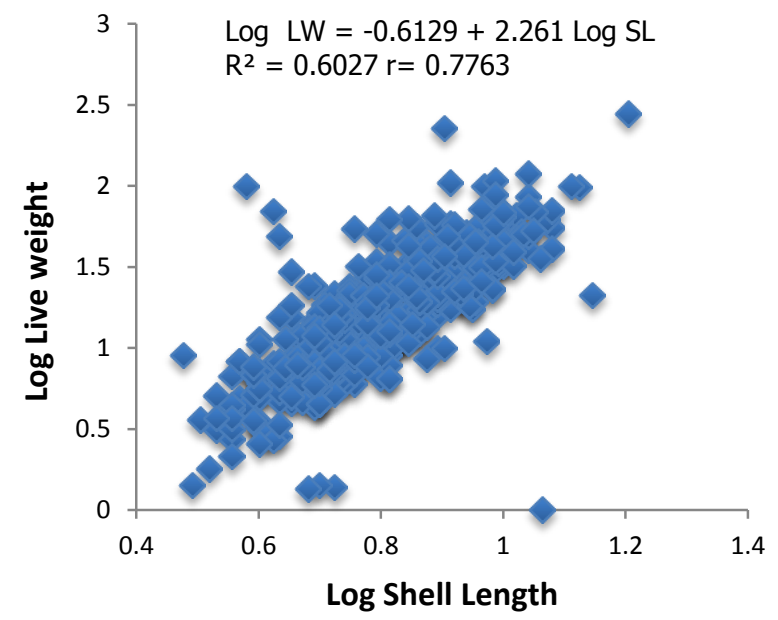

Figure 1: Log shell length - Log live weight relationship of Galatea paradoxa from Itu Creek

The values of " $b$ " (1.6332) and " $r$ "(0.6855) in Figure 2 showed negative allometric growth and a positive correlation between the shell length and flesh weight.

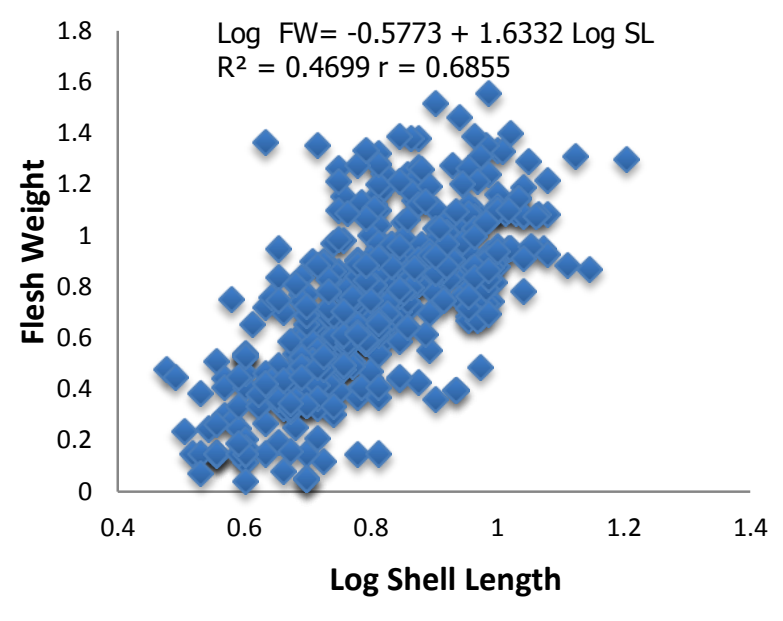

Figure 2: Log shell length - Log flesh weight relationship of Galatea paradoxa from Itu Creek The value of "b", 2.4733 in Figure 3 representsnegative allometric growth whiles the correlation coefficient of 0.7701 indicates a strong correlation (close to ' 1 ') between its shell length and shell weight. 


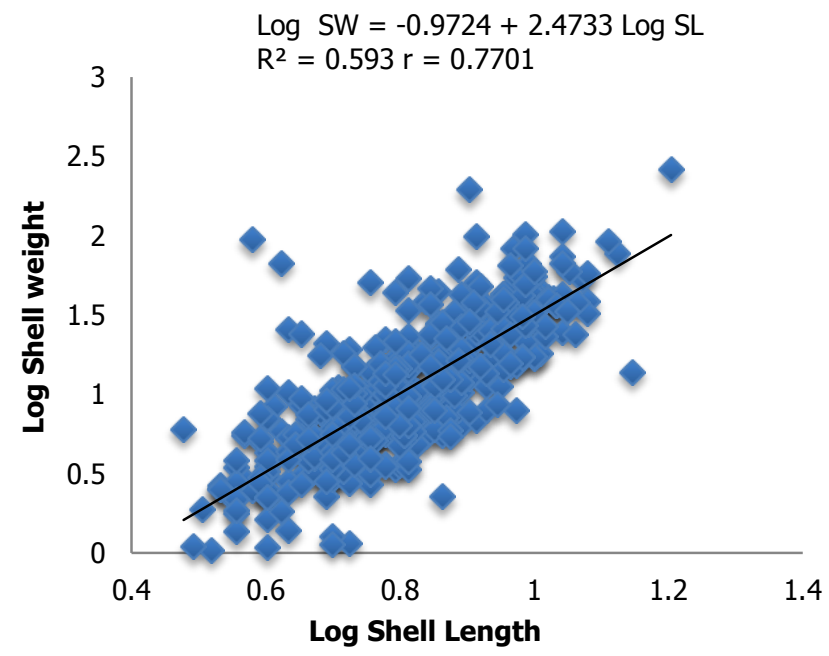

Figure 3: Log shell length - Log shell weight relationship of Galatea paradoxa from Itu Creek As shown in Figure 4, the maximum height and shell weight are weekly correlated $(b=0.9768 ; r$ $=0.4525$ ).

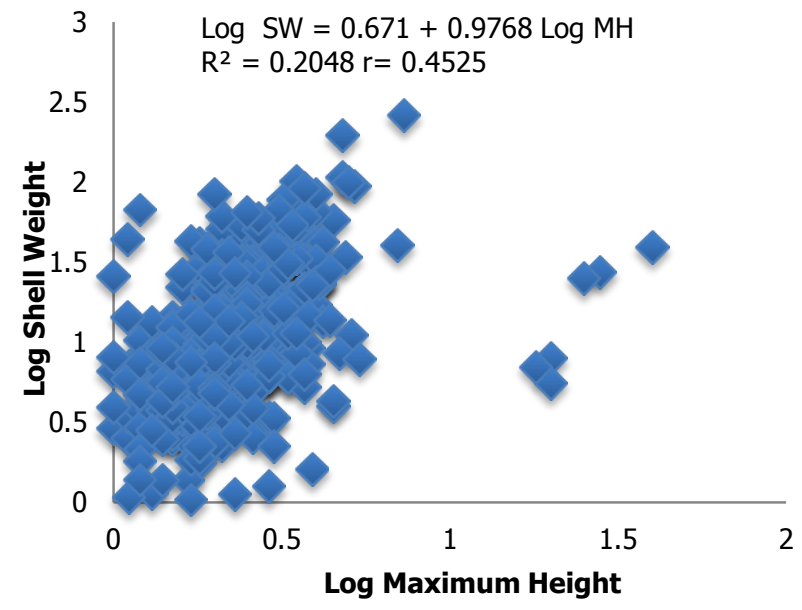

Figure4: Log max. height- Log shell weight relationship of Galatea paradoxa from Itu Creek The value of "b", 1.1443 in Figure 5 represents negative allometric growth while the correlation coefficient of 0.4667 indicates a week correlation (far from '1') between its nacrewidth and shell weight.

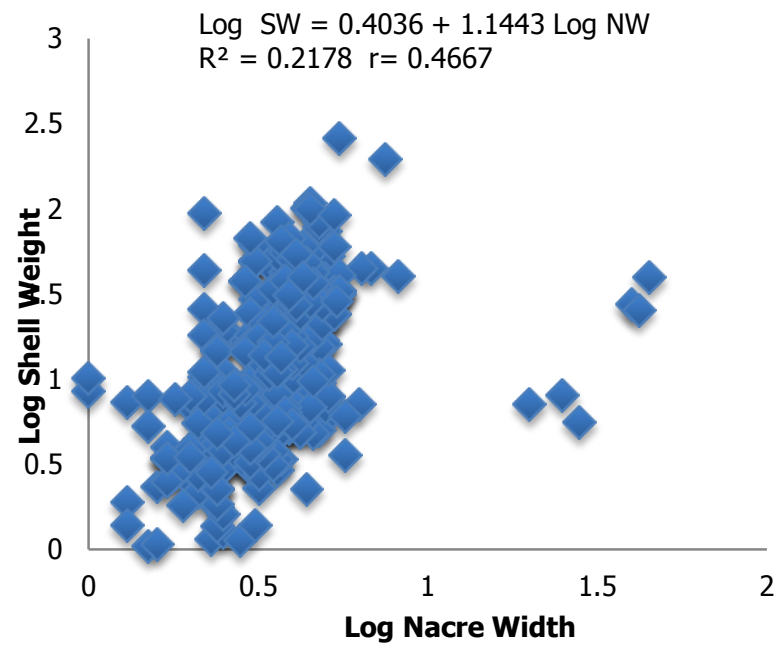

Figure 5: Log nacrewidth - Log shell weight relationship of Galatea paradoxa from Itu Creek The West African Clam according to Figure 6, exhibited a negative allometric growth $(b=1.2354)$ and a weak correlation ( $r=0.4664)$ between its maximum width and shell weight.

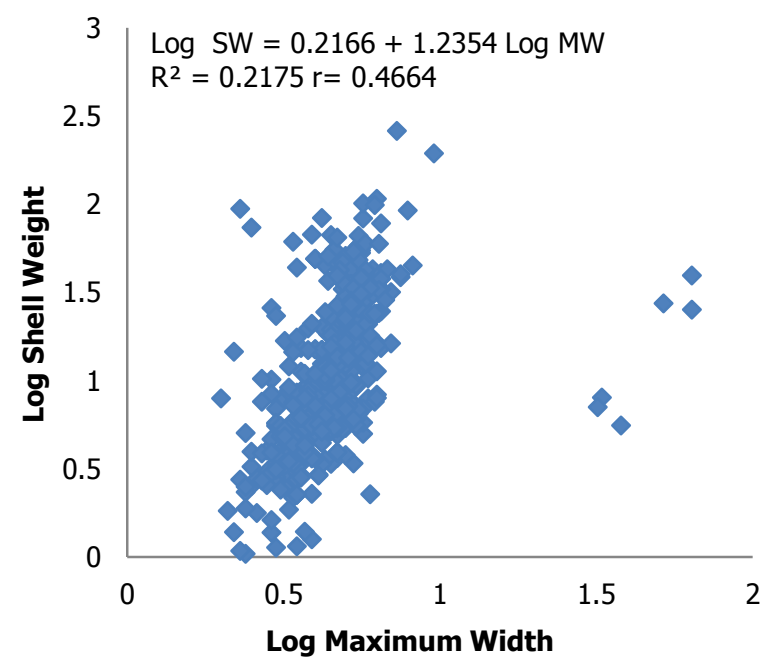

Figure 6: Log max.width - Log shell weight relationship of Galatea paradoxa from Itu Creek Also in Figure 7, the shell length and maximum width are weekly correlated $(b=0.6136 ; r=$ 0.5067). 


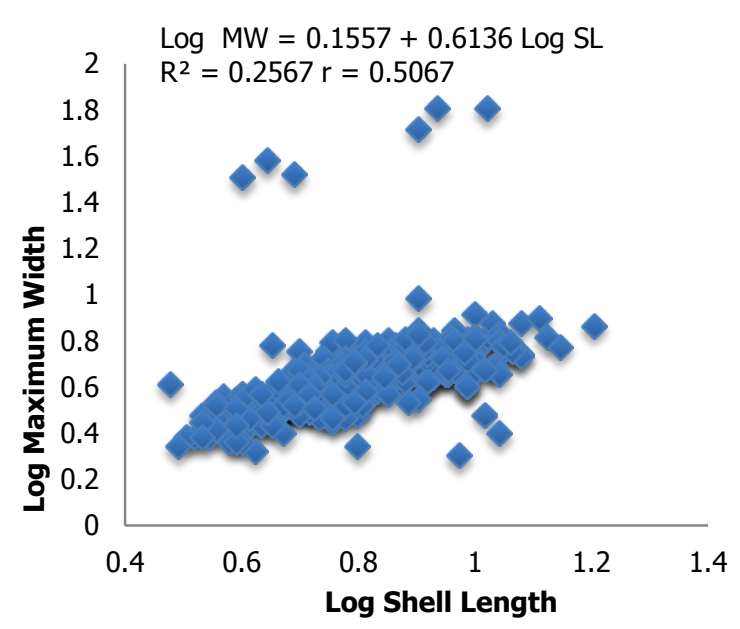

Figure 7: Log shell length - Log max. width relationship of Galatea paradoxa from Itu Creek The value of "b", 0.5792 in Figure 8 represents negative allometric growth while the correlation coefficient of 0.3949 indicates a week correlation (far from '1') between its shell length and the maximum height.

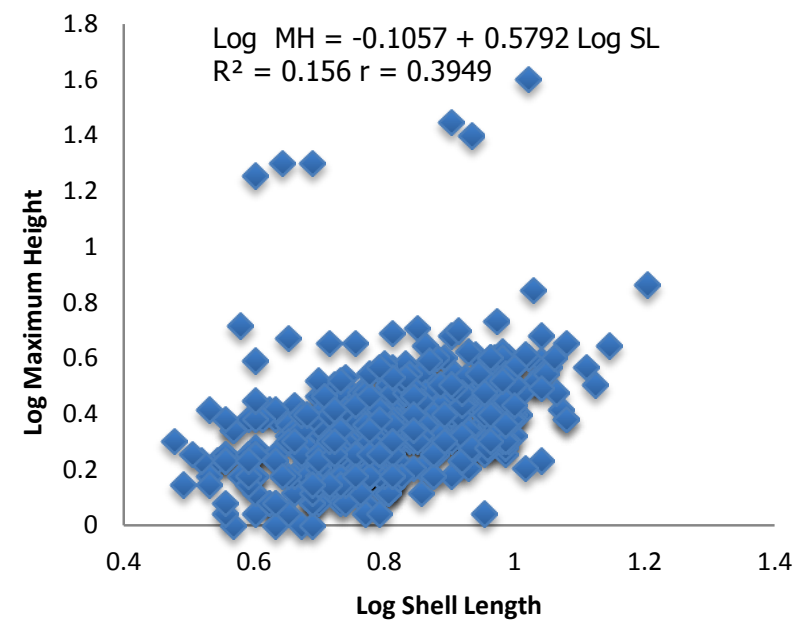

Figure 8: Log shell length - Log max. height relationship of Galatea paradoxa from Itu Creek The values of " $b$ " (0.6609) and " $r$ " (0.5051) in Figure 9 showed negative allometric growth and a fair correlation between the shell length and nacre width.

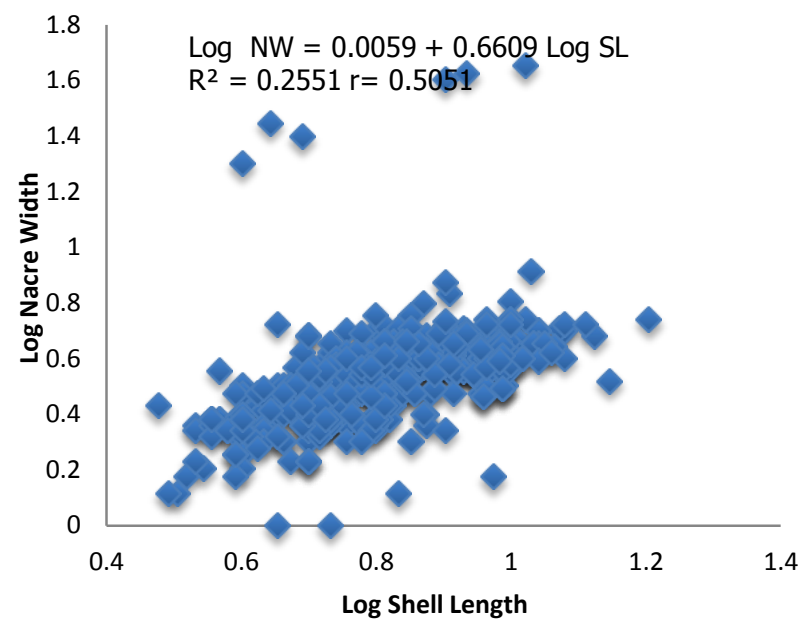

Figure9: Log shell length - Log nacre width relationship of Galatea paradoxa from Itu Creek The relationship among log shell dimensions of Galatea paradoxa from Itu Creek are presented in the regression equations shown below:

$L W=-0.6129 \mathrm{SL}^{2.261} \quad\left(\mathrm{R}^{2}=0.6027, r=0.7763\right.$, $\mathrm{N}=816$ )

$F W=-0.5773 S L^{1.6332} \quad\left(R^{2}=0.4699, r=0.6855\right.$, $\mathrm{N}=816$ )

$S W=-0.9724 S^{2.4733} \quad\left(R^{2}=0.5930, r=0.7701\right.$, $\mathrm{N}=816$ )

$\mathrm{SW}=0.671 \mathrm{MH}^{0.9768} \quad\left(\mathrm{R}^{2}=0.2048, \mathrm{r}=0.4525\right.$, $\mathrm{N}=816)$

$S W=0.4036 W^{1.1443} \quad\left(R^{2}=0.2178, r=0.4667\right.$,

$\mathrm{N}=816$ )

$\mathrm{SW}=0.2166 \mathrm{MW}^{1.2354} \quad\left(\mathrm{R}^{2}=0.2175, r=0.4664\right.$,

$\mathrm{N}=816$ )

$M W=0.1557 S L^{0.6136} \quad\left(R^{2}=0.2567, r=0.5067\right.$,

$\mathrm{N}=816$ )

$\mathrm{MH}=-0.1057 \mathrm{SL} 0.5792 \quad\left(\mathrm{R}^{2}=0.1560, r=0.3949\right.$,

$\mathrm{N}=816$ )

$N W=0.0059 S^{0.6609} \quad\left(R^{2}=0.2551, r=0.5051\right.$, $\mathrm{N}=816$ )

\section{DISCUSSION}

In this study, the exponents were generally lower than 3 , indicating negative allometric growth. The correlation coefficients $(r)$ in all the shell variables were below ' 1 ', showing a week correlation between the parameters. Thus, indicating that the clam (Galatea paradoxa) body forms did not grow at the same proportion i.e growth in length is not 
proportional to weight. This finding conforms to the works of Moruf and Ojetayo (2017) and Lawal-Are et al., (2019) on mangrovecrustaceans of Lagos Lagoon.

Growth pattern for the clam was based on the length/weight relationship. The shell length of the West African Clam, G. paradoxa examined in this study was higher than $7.01 \pm 0.34 \mathrm{~cm}$ reported by Kingdom et al. (2012) for G. paradoxain Ikebiri Creek. Likewise, the $63.26 \pm 0.50 \mathrm{~mm}$ recorded by Ehigiator and Osawaru (2016) for Egeriaradiata in the Forcados River was smaller. The mean live weight in this study was higher than the highest value of $41.32+0.61$ reported for the same species in the Volta River Estuary (Obirikokang et al., 2013). The differences in the weights of these clams may be physiological and could be a function of environmental parameters. As recommended by Moses (1990), the landing of young clams $(<6.0 \mathrm{~cm}$ shell length) should be prohibited to sustain optimum harvest. Soft tissue yield of the clam in this study was lower than $24 \%$ reported by Bascinar et al. (2009) for Swan mussel in Lake Chad, Turkey and $37.7 \%$ observed by Cetinkaya (1996) for Uniostevenianus in Golmarmara. According to Ehigiator and Osawaru (2016), the growth of an individual clam could be limited due to the direct investment of energy to shell growth instead of the soft tissue. This is due to the need for strong shell and a high capacity to live in adverse conditions.

Observed values of the regression coefficient (b) for G. paradoxa in this study were less than 3, indicating negative allometric growth. This is in conformity with what were recorded for Pernaviridisfrom Bangladesh coastal waters (Khan et al, 2010) and Tympanotonus fuscatus from Lagos Lagoon (Moruf and Lawal-Are, 2015) but contrary to the positive allometry recorded for Portunus validus in Lagos coast(Moruf and Lawal-Are, 2017). The correlation coefficients (r) in all the shell variables were below ' 1 ', showing a week correlation between the parameters. Bivalve growth and the allomentry between the shell and the flesh are known to be affected by the animal reproductive condition, population status and physicochemical variables of habitat (Ehigiator and Osawaru, 2016).The growth activity could also be determined by the sex of the organism, quantity and quality of food available, salinity and water temperature (Dall et al., 1990; Akinjogunla and Moruf, 2018). The week correlations among the shell dimensions for $G$. paradoxa in this study is similar to the observation of Gimin et al.(2004) for P. erosa, but contrary to what were reported by Ross and Lima (1994) and Deval (2001) for Dreissena spp and Chamelea galllina respectively.

\section{CONCLUSION}

The West African Clam, G. paradoxa in Itu Creek exhibits negative allometric growth pattern and lack strong correlation within shell dimensions; this is typical of many bivalve molluscs.About $19 \%$ of the live weight of the clam species is made up of flesh by weight.

\section{ACKNOWLEDGEMENT}

The assistance of Dr. O. J. Akinjogunla of the Dept. of Microbiology, University of Uyo, during sample collection is appreciated.

\section{REFERENCE}

Adeyemo, A.O., Onuha, G. andlnyang, I. (2013).Parasitic survey of clam (Galatea paradoxa) from two locations in Southern ljaw local government area of Bayelsa state, Nigeria.Journal of Environmental Science and Technology, 1(3):66-70.

Adjei-Boateng, D., Amisah, S. and Quagrainie, K. K. (2009).Bacteriological contamination of the freshwater clam (Galatea paradoxa) from the Volta estuary, Ghana.African Journal of Microbiology Research,3(7): 396399.

Akinjogunla, V.F. and Moruf, R.O. (2018).The ecology and growth biology of Farfantepenaeusnotialis (Pérez-farfante, 1967) from an open tidal estuary in Nigeria.Nigerian Journal of Fisheries, 15(1): $1326-1335$. 
Bascinar, N. S., Duzgunes, E., Selim-Misir, D., Polat, H. and Zengin, B. (2009). Growth and flesh yield of Swan mussel (Anodontacygnea Linnaeus, 1758) (Bivalves: Unionidae) in Lake Chad, Kars, Turkey).Turkish Journal of Fisheries and Aquatic Sciences, 9(2): 127-132.

Cetinkaya, O. (1996).A freshwater mussel species UniostevenianusKrynicki 1837 (Mollusca: Bivalvia: Unionidae) from the river Karasu flowing into Lake Van, Turkey. Turkish Journal of Zoology, 20(2): 169 173.

Dall, W., Hill, B. J., Rothlisberg, P. C. and Staples, D. J. (1990).Biology of the Penaeidae. In: Blaxter, J.H.S., Southward, A.J. (Eds.), Advances in Marine Biology, vol. 27.Academic Press, London. 489pp.

Deval, M. C. (2001). Shell growth and biometry of the striped Venus Chameleagallina $(\mathrm{L})$ in the Marmara Sea.Turkey Journal of Shellfish Research, 20 (1): 155-159.

Ehigiator, F. A. R. and Osawaru, E. (2016). Shell growth pattern of the Freshwater Clam (Egeriaradiata) in the Forcados River, Niger Delta, Nigeria. Nigerian Journal of Agriculture, Food and Environment, 12(2):92-97.

Etim, L. and Brey, T. (1994).Growth, productivity and significance for fishery of the bivalve Egeriaradiata (Donacidae) in the Cross River, Nigeria.Archive of fishery and marine research, 42(1): 63-75.

Gallardi, D. (2014). Effects of bivalve aquaculture on the environment and their possible mitigation: a review. Fisheries and Aquaculture Journal, 5(3):1 - 8

Gimin, R., Mohan, R., Thinh, L. V. and Driffiths, A. D. (2004).The relationship of Shell Dimensions and Volume to Live weight and Soft Tissue weight in the mangrove clam Polymesodaerosa (Solander 1786) from Northern Australia.NAGA, World Fish Center Quarterly, 27.(3\&4): 32 - 34.

Guimaraes-Silva, A.A, Shinozaki-Mendes, R.A and Andrade, H. A. (2015). Morphometric analysis of swimming crabs
Callinectesdanae (Crustacea, Portunidae) from the Santa Cruz Canal, Pernambuco (Brazil). Pan-American Journal of Aquatic Sciences, 10(3): 203-211.

Ikpeme, E. V. and Johnny,U. U.(2018).Morphometric Characterisation of Freshwater Clam (Egeriaradiata) in Three Geographic Locations of South-South Nigeria. Journal of Advances in Biology \& Biotechnology, 19(1): 1-9.

Khan, M.A.A., Assim, Z.B. and Ismail, N. (2010): Population Dynamics of the Green - lipped mussel, Pernaviridis from the offshore waters of Naf River coast, Bangladesh. Chiang Mai Journal of Science, 37(2): 344 354.

Kingdom, T., Allison, M.E. andGbenefadei, P. (2012). Shell growth of fresh water clam (Galatea paradoxa) in Ikebiri creek, Bayelsa state, Nigeria. International Journal of Applied Research and Technology, 1(6): 215- 219.

Kumar, S.A., Thushari, G.G.N. and Jayasena, D. D. (2018).Comparative analysis of morphological characteristics of clam (Marcia opima) in mannar coastal belt, Sri Lanka.International Journal of Fisheries and Aquatic Studies, 6(3): 392-399.

Lawal-Are, A. O., Moruf, R. O., Akubueze, K. L. and Adewole, O. (2019).Morphometric characteristics of two walking crabs, Cardiosomaarmatum (Gecarcinidae) and Goniopsispelii (Graspidae) from a tropical mangrove swamp in Lagos, Nigeria.Nigerian Journal of Agriculture, Food and Environment, 15(1):83-88.

Moruf, R. O. and Akinjogunla, V. F. (2018).Photometric determination of macromicro minerals in the West African Mud Creeper, Tympanotonusfuscatusvar radula (Linnaeus, 1758).Journal of Experimental Research,6(3): 35-40.

Moruf, R.O. and Lawal-Are, A. O. (2015).Growth pattern, whorl and girth relationship of the periwinkle, Tympanotonusfuscatusvar radula(Linnaeus, 1758) from a tropical estuarine lagoon, Lagos, 
Nigeria.International Journal of Fisheries and Aquatic Studies, 3(1): 111-115.

Moruf, R.O. and Lawal-Are, A. O. (2017). Size composition, growth pattern and condition factor of two Portunid crabs, Callinectesamnicola (De Rochebrune) and Portunusvalidus (Herklots) from Lagos Coast, Nigeria. Nigerian Journal of Fisheries and Aquaculture, 5(1): $15-21.2$.

Moruf, R. O and Ojetayo, T. A. (2017). Biology of the West African Fiddler Crab, Ucatangeri (Decapoda: Ocypodidae) from a Mangrove Wetland in Lagos, Nigeria. International Journal of Aquatic Biology, 5(4): 263-267.

Moses, B.S. (1990). Growth, biomass, mortality, production and potential yield of the West african clam, Egeriaradiata (Lamarck) (Lamellibranchia, Donacidae) in the Cross River System, Nigeria. Hydrobiologia, 196 (1):1 - 15 .

Obirikokang, K. A., Adjei-Boateng, D., Madkour, H. A., Amisa, S. and Otchere, F.A. (2013). Length-Weight relationship of the freshwater clam Galatea paradoxa(Born 1778) from the Volta River estuary, Ghana. Pakistan Journal of Biological Sciences, 16(4):185189.
Oke, C. (2000). Molluscsin biodiversity: Biological Environment and Resources. NDES (Niger Delta Environmental Survey) Report 2: 203260.

Parson, R. (1988). Statistical analysis- a decision making approach. Second edition. Harper and Row publishers, New York.791pp.

Pauly, D. (1983).Some simple methods for the assessment of tropical stocks.FAO Fish. Tech. Pap., 234: 52.

Ross, T. K. and Lima, G. M. (1994). Measures of allometric growth: the relationships of shell length, shell weight and volume to ash-free weight in zebra mussel, Dreissenapolymorphapallasand Quagga mussel,DreissenabugensisAndrusov.

Proceedings of the fourth International Zebra Mussel conference. Madison, Wisconsin. 